\title{
A Comprehensive Review on Botanicals as Anti-ulcer Therapeutics: Prospective Avenues of Biocompatible Drug Discovery
}

Prabhakar Singh Tiwari ${ }^{*}$ Jitender K Malik

Dept. of Pharmacy, Shri Rawatpura Sarkar University-Raipur (C.G.)-India

DOI: $\underline{10.36348 / \text { sijtcm.2020.v03i02.003 }}$ | Received: 04.02.2020 | Accepted: 11.02 .2020 | Published: 16.02 .2020

*Corresponding author: Prabhakar Singh Tiwari

\section{Abstract}

Peptic ulcer is a frequent disease of the Gastro Intestinal tract. It is mostly an inflamed break in the skin or the mucus membrane lining the alimentary tract. When there is a disturbance of the normal equilibrium caused by either enhanced aggression or diminished mucosal resistance ulceration occurs. Divergent to trendy belief, ulcer is not caused by spicy food but instead is most usually due to either an infection or long term use of medications. A combination of drugs like antibiotics and proton pump inhibitors is standard treatment of the peptic ulcer. However these drugs are expensive and are probable to produce more side effects when compared to herbal medicines Nevertheless, many studies revealed that Botanicals and their phytoceuticals can efficiently treat peptic ulcer in humans and a range of animal models. In the present review, attempts have been made to recognize about some of the common Indian medicinal plants which may be used in treatment or prevention of peptic ulcers.

Keywords: Peptic ulcer, Botanicals, Phytoceuticals \& Herbal medicine.

Copyright @ 2020: This is an open-access article distributed under the terms of the Creative Commons Attribution license which permits unrestricted use, distribution, and reproduction in any medium for non-commercial use (NonCommercial, or CC-BY-NC) provided the original author and source are credited.

\section{INTRODUCTION}

An ulcer is the inflamed crack in the skin or mucus membrane lines the stomach or duodenum. Peptic ulcer is the most frequent disease of the GI Tract. When there is a disturbance of the normal equilibrium caused by either enhanced aggression or diminished mucosal resistance ulceration occurs [1]. Bile acid regurgitation also may injuries the gastric mucosa and weakens the barrier of gastric mucosal. The main cause of peptic ulcer includes H.pylori infection Non-steroidal anti-inflammatory drugs, critical illness (stress-related mucosal damage) however some uncommon causes includes Hyper-secretion of gastric acid (e.g., ZollingerEllison syndrome), viral infections (e.g., cytomegalovirus), vascular insufficiency (crack cocaine-associated) Radiation Chemotherapy and rare genetic subtypes [2].

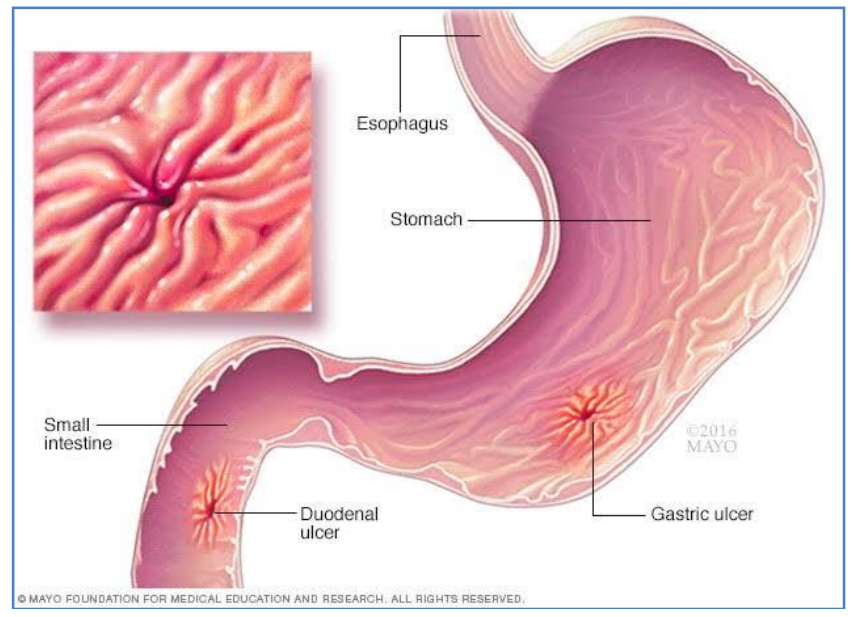

Peptic ulcer 


\section{Pathogenesis of Peptic ulcer [3]}

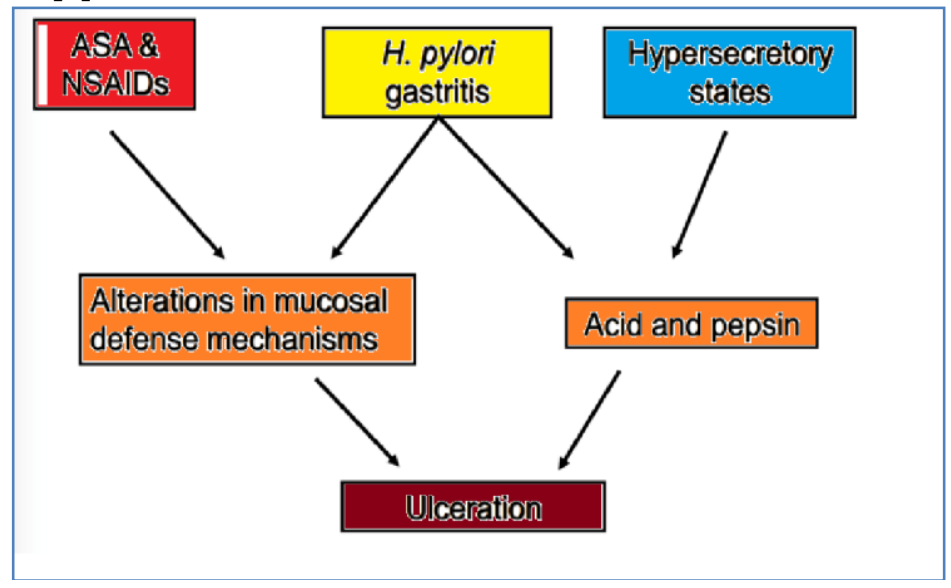

Major part in all traditional systems of medicine constitutes an herbal drug. There are approximately 1300 Indian medicinal plants which are used in formulating therapeutic preparations according to Ayurvedic and other traditional systems of medicine $[4,5]$.

Role of Phytoceuticals in Peptic Ulcer

\begin{tabular}{|c|c|c|}
\hline Phytoceuticals & Proposed Mechanism of Action & Reference \\
\hline Flavonoids & $\begin{array}{l}\text { - Anti-secretory mechanism of action of Quercetin. } \\
\text { - Flavonol has antihistaminic properties, thus, decreases histamine levels, as } \\
\text { well as preventing the release of histamine from gastric mast cells and } \\
\text { inhibiting the gastric } \mathrm{H}+\mathrm{K}+\text { proton pump, diminishing acid gastric } \\
\text { secretion. } \\
\text { Chalcones, possess cyto-protective effects, which increase the mucosal } \\
\text { blood flow, stimulate the synthesis of muco-substances in the gastric } \\
\text { mucosa and increase PGs levels. } \\
\text { - Antioxidant potential (garcinol, rutin and quercetin). }\end{array}$ & 6 \\
\hline Tannins & $\begin{array}{ll}\text { - } & \text { Promotion of tissue repair } \\
\text { - } & \text { Acid secretion inhibition, } \\
\text { - } & \text { Antioxidant } \\
\text { - } & \text { Anti-Helicobacter pylori activity }\end{array}$ & 7 \\
\hline Alkaloids & $\begin{array}{l}\text { - Stimulates these neurons and signalizes for protection inhibiting the } \\
\text { acid secretion( In the stomach, capsaicin }(0.3 \text { nanolmol/kg }-10 \\
\mathrm{mg} / \mathrm{kg} \text { ). } \\
\text { - Mainly increasing the gastric mucosal blood flow which aid in prevention } \\
\text { and healing of ulcers. } \\
\text { Decreases in gastric acid/pepsin secretions and protection of the } \\
\text { mucous membrane (Nigakinon \& methylnigakinone are also indole } \\
\text { alkaloids) }\end{array}$ & 8 \\
\hline Saponin & $\begin{array}{l}\text { - Action is mediated by the formation of mucous on the gastric mucosa( } \\
\text { generally those of triterpene type like glycyrrhetinic acid and } \\
\text { carbenoxolone). } \\
\text { Anti-secretory mechanism; they inhibit acid secretion, total acid output, } \\
\text { and lower the pH of gastric juice. }\end{array}$ & 10 \\
\hline Triterpenoids & $\begin{array}{l}\text { - } \\
\text { - Anti-inflammatory and anti-ulcer activities } \\
\text { - } \quad \text { panti-ulcerogenic effects via cytoprotective action by increase mucus } \\
\text { - } \quad \text { Anprove gastric mucosal blood flow and bicarbonate secretion. } \\
\text { peroxide content and elevation of SOD activity in the stomach. }\end{array}$ & 11 \\
\hline Polysaccharides & $\begin{array}{l}\text { - Cytoprotective agents i.e stimulate mucosal regeneration and proliferation } \\
\text { and increase PG synthesis, restoring the gastric mucus levels. }\end{array}$ & 12 \\
\hline
\end{tabular}


Indian Medicinal plant having antiulcer Potential India is gifted with varieties of large number of medicinal herbs because of variety of climatic conditions and seasons favorable for growth of many species of plants. India is well famous as the "Emporium of Medicinal Plants". Due to their enormous importance, demand of medicinal plants has increased numerous folds [13].

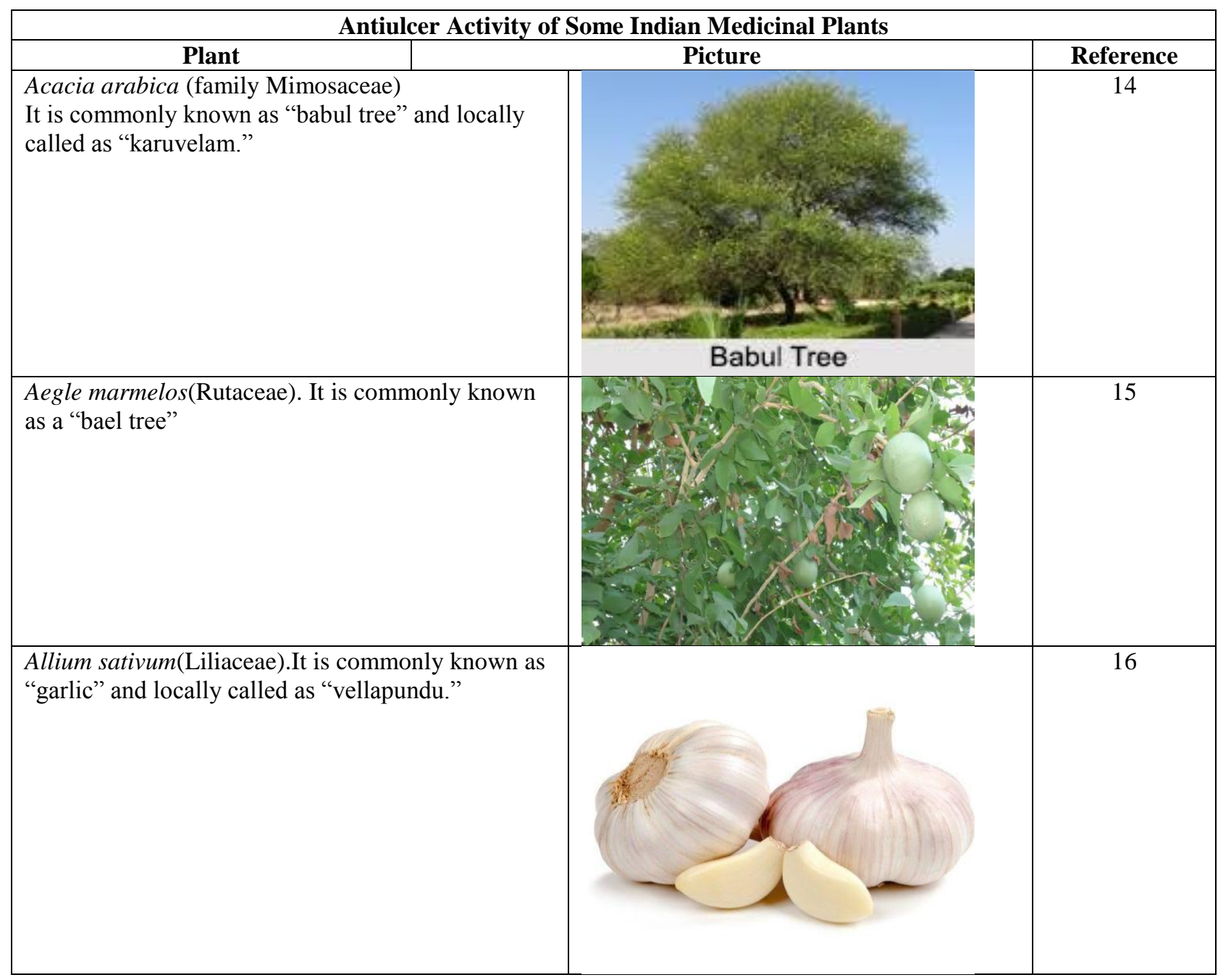

Adansonia digitata (Malvaceae). It is commonly known
as "boabab or monkey-bread tree of Africa." It is locally
known as "paparapuli."




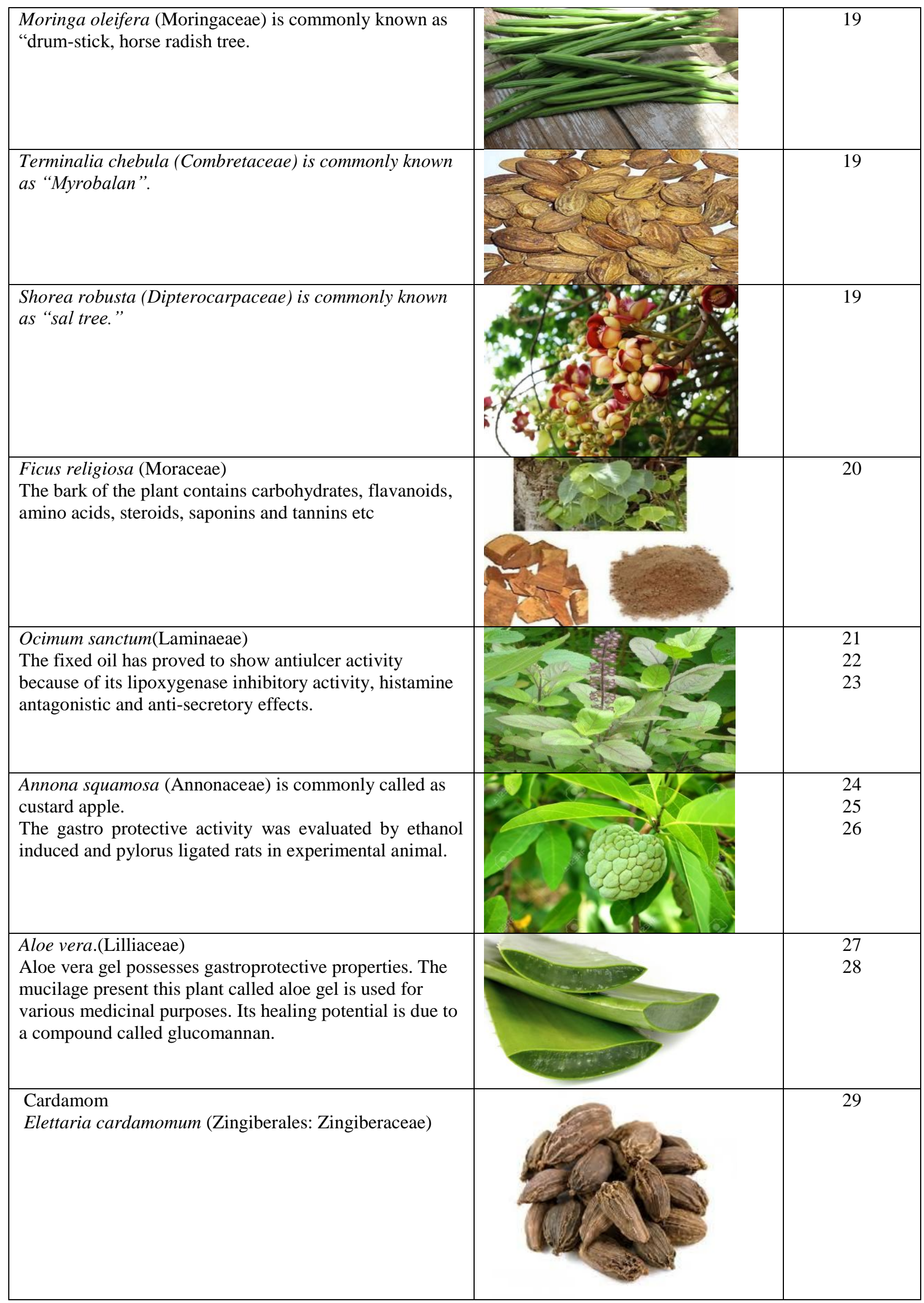




\begin{tabular}{|c|c|c|}
\hline \multicolumn{3}{|c|}{ Previous work done on Anti-ulcer } \\
\hline Plant & Experiment outcome & Reference \\
\hline Lagenaria siceraria & $\begin{array}{l}\text { The chloroform extract of Lagenaria siceraria at } 250 \mathrm{mg} / \mathrm{kg} \text { dose has shown } \\
\text { mucosal erosion, the partial healing of ulcer with few inflammatory cells and } \\
\text { the dose } 400 \mathrm{mg} / \mathrm{kg} \text { has shown healing ulcer, mucosa and no inflammation of } \\
\text { cells. L. siceraria is speculated to be recognized for its antioxidant property, } \\
\text { which in turn could be linked to existence of flavonoids and polyphenolic } \\
\text { compounds, saponins and tannins. }\end{array}$ & 30 \\
\hline Polycarpea aurea & $\begin{array}{l}\text { Methanolic extract of Polycarpea aurea was investigated for antiulcer } \\
\text { activity. The result showed that the methanolic extract of } P \text {. aurea is having } \\
\text { an antiulcer activity in the aspirin plus pylorus ligated rat model. }\end{array}$ & 31 \\
\hline Strychnor potatorum & $\begin{array}{l}\text { SP-1 an active compound was isolated from the seeds of Nirmali (Strychnor } \\
\text { potatorum) and its antiulcer potential was studied against ethanol, } \\
\text { hydrochloric acid, indomethacin, stress and pyloric ligation induced gastric } \\
\text { Ulceration in albino rats. A significant outcome was observed in all the } \\
\text { models. }\end{array}$ & 32 \\
\hline Osyris quadripartita & $\begin{array}{l}\text { Anti-ulcer activity of } 80 \% \text { methanol leaf extract of OQ in rats was stuied. The } \\
\text { effect of OQ extract on gastric ulcer in rats in pylorus ligation-induced and } \\
\text { ethanol-induced models was studied using single dosing }(100,200,400 \\
\mathrm{mg} / \mathrm{kg} \text { ) and repeated dosing ( } 200 \mathrm{mg} / \mathrm{kg} \text { for } 10 \text { and } 20 \text { days) approaches. The } \\
\text { result of this study proved that OQ has anti-ulcer pharmacologic activity due } \\
\text { to one or more of the secondary metabolites present in it. }\end{array}$ & 33 \\
\hline Carum carvi seed & $\begin{array}{l}\text { Ethanolic and aqueous extracts of seeds extract Carum carvi at a dose of } 100 \\
\text { and } 200 \mathrm{mg} / \mathrm{kg} \text { b.w. respectively was investigated for anti-ulcer activity. The } \\
\text { result revealed that both the extracts significantly caused the reduction in } \\
\text { gastric content, total acidity, ulcer index, and increase in pH of gastric pylorus } \\
\text { ligation ulcer model. In comparison with the standard drug, the results of } \\
\text { hydro alcoholic extract at } 100 \mathrm{mg} \text { dose showed good analgesic and at } 200 \mathrm{mg} \\
\text { dose showed antiulcer activity. }\end{array}$ & 34 \\
\hline Coccinia grandis & $\begin{array}{l}\text { Antiulcer activity of Coccinia grandis leaves against indomethacin induced } \\
\text { gastric ulcer model was studied. The ethanolic leaf extract of Coccinia } \\
\text { grandis showed significant potential. }\end{array}$ & 35 \\
\hline $\begin{array}{l}\text { Mussaenda philippica } \\
\text { (Rubiaceae) }\end{array}$ & $\begin{array}{l}\text { Aqueous extract of } M \text {. philippica leaves exhibited potential antiulcer activity } \\
\text { in experimental rat models. }\end{array}$ & 36 \\
\hline
\end{tabular}

\section{CONCLUSION}

The present review focuses on role of various phytoceuticals in ulceration along with their possible mechanism of action. The review is lightened list of various Indian medical used to be cure and prevent ulceration. Herbalism provides leads to find therapeutically useful compounds, thus more efforts should be made towards isolation and characterization of active compounds and their structure elucidation. The combination of traditional and modern knowledge can produce better drugs for proper ulceration care with fewer adverse effects.

\section{REFERENCE}

1. Grossman, M. (2009). "Peptic ulcer: A guide for the practicing physician", American Journal of Pharmacology and Toxicology, 4, 89-93.

2. Amandeep, K., Robin, S., Ramica, S., Sunil, K. (2012). Peptic ulcer: A review on etiology and pathogenesis. Int J Clin Pharm, 3:34-38.

3. Maity, P., Biswas, K., Roy, S., Banerjee, R.K., Bandyopadhyay, U. (2003). Smoking and the pathogenesis of gastroduodenal ulcer-recent mechanistic update. Mol Cell Biochem, 253: 329338.

4. Himesh, S., \& Singhai, A.K. (2012). Recent Update of Botanical For Wound Healing Activity. IRJP, $3 ; 7,1$.

5. Himesh, S., \& Akhlesh, K.S. (2012). Recent Updates on the Genus Coleus. Asian Journal of Pharmaceutical and Clinical Research, 5; 1, 12.

6. Kelly, S., de L.M. (2009). Flavonoids with Gastroprotective Activity. Molecules, 14, 1007.

7. Neyres, Z.T., De, J. (2012). Tannins, Peptic Ulcers and Related Mechanisms. Int J Mol Sci, 13; 3, 3203-3228.

8. Heloina de Sousa, F. (2018). Gastric and Duodenal Antiulcer Activity of Alkaloids: A Review. Molecules, 13; 12, 3198-223.

9. Guaraldo, L., Sertiè, J.A., Bacchi, E.M. (2001). Anti-ulcer action of the hydroalcoholic extract and fractions of Davilla rugosa Poiret in the rat. $J$ Ethnopharmacol, 76, 191-5.

10. Awaad, A.S., El-Meligy, R.M., Soliman, G.A. (2013). Natural products in treatment of ulcerative colitis and peptic ulcer. J. Saudi Chem. Soc. 17, 101-124. 
11. Inas, Z.A., Hala, A.K., Gehan, H.H. (2011). Gastroprotective effect of Cordia myxa L. fruit extract against indomethacin-induced gastric ulceration in rats. Life Sci. J. 2011, 8, 433-445.

12. Awaad, A.S., El-Meligy, R.M., Soliman, G.A. (2013). Natural products in treatment of ulcerative colitis and peptic ulcer. J. Saudi Chem. Soc, 17, 101-124.

13. Himesh Soni, A.K. Singhai, J.k. Malik., \& Sarvesh, S. (2013). Antimicrobial and Anti-inflammatory Activity of the Hydrogels Containing Rutin Delivery. Asian Journal of Chemistry; 25(15), 8371-8373.

14. Nadkarni's, K. M. (1976). Indian Materia Medica, Popular Prakashan, Mumbai, India, 1; 9-10

15. Omayma, K. H., Mohamed, M. Y., \& M. Elnaa. (2011). "Possible protective effect of Gum Arabic on experimentally induced gastric ulcer in adult male albino rats: a histopathological and immunohistochemical study," Egyptian Journal of Histology, 34, 546-553,

16. Kumari S.T., Ayyanar, M., Udayakumar, M., \& Sekar, T.(2011). "Ethnomedicinal plats used by Kani tribals in Pechiparai forests of Southern Western Ghats, Tamilnadu, India," International Research Journal Plant Science, 2(12), 349-354.

17. Nadkarni's, K. M. (1976). Indian Materia Medica, Popular Prakashan, Mumbai, India, 1;561-563.

18. Nadkarni's, K. M. (1976). Indian Materia Medica, Popular Prakashan, Mumbai, India, 1; 1132-1133.

19. Nadkarni's, K. M. (2001). Indian Materia Medica, Popular Prakashan, Mumbai, India, 1205-1210.

20. Mohammed, S.A.K., Hussain, S.A., Jaisl, A.M.M., Zakarial., Z.A., Khan, M. (2011). "Anti-ulcer activity of Ficus religiosa stem bark ethanolic extract in rats", Journal of Medicinal Plants. 5, 354-359.

21. Khan, M.S.A., Hussain, S.A., Jais, A.M.M., Zakaria, Z.A., Khan, M. (2011). Anti-ulcer activity of Ficus religiosa stem bark ethanolic extract in rats, Journal of Medicinal Plants Research, 5(3), 354-359.

22. Vinod, K., Andola, H.C., Lohani, H., Chauhan, N. (2011). Pharcological review on ocimum sanctum Linnaeus: A queen of herbs, Journal of pharmacy research, 4(2), 366-368.

23. Singh, S., Majumdar, D.K. (1999). Evaluation of the gastric antiulcer activity of fixed oil- Ocimum sanctum (Holy basil), Journal of Ethnopharmacology, 65, 6513-6519.

24. Himesh, S., Singhai, A.K., Malik, J.K., \& Sarvesh, S. (2012). Evaluation of Leaves of Aqueous Extract of Coleus Aromaticus and Methanolic
Extract of Annona Squamosa Extracts on Cell Viability. Am. J. PharmTech Res, 2(4), 935.

25. Soni, H., Singhai, A.K., \& Sharma, S. (2010). Quantitative estimation of DNA isolated from various parts of annona squamosa. IRJP, 2(12); 169-171.

26. .Mohammad, Saleem, T.S., Pradeep, K.R., Priyanka, N., Madhuri, M., Sravanti, U., Sarala, K.(2012). "Anti-ulcerogenic activity of aqueous extract of Annona squamosa Linn”, International Journal of Research in Phytochemistry and Pharmacology, 2(3), 157-159.

27. Soni, H. (2011). Qualitative and quantitative profile of aloin isolated from Aloe Vera., IRJP. 2; $9,1$.

28. Keshavarzi, Z., Rezapour, T.M., Vatanchian, M., Zare Hesari, M., Nabizade Haghighi, H., Izanlu, M., Sabaghian, M., Shahveisi, K. (2014). The effects of aqueous extract of Aloe vera leaves on the gastric acid secretion and brain and intestinal water content following acetic acid- induced gastric ulcer in male rats, Avicenna Journal of Phytomedicine, 4(2), 137-143.

29. Anwar, J., Farah, A., Siddique, Mohd, A. (2005). Antiulcerogenic activity of Elettaria cardamomum Maton and Amomum subtulatum Roxb. Seeds, Indian Journal of Traditional knowledge, 4; 3, 298 302

30. Prashanth, M. (2019). Evaluation of Anti-Ulcer Activity of Lagenaria siceraria Chloroform Extracts in Pylorus Ligated Rats. Electronic Journal of Biology, 15;1, 027-37.

31. Chandra, S.K. (2019). Anti-Ulcer Activity of Methanolic Extract of Polycarpea aurea in Asprin Plus Pylorus LigationInduced Ulcer Model in Rats. J. Pharm. Sci. \& Res. 11; 7, 2689-2693.

32. Prasanta, K.M. (2013). Antiulcer Activity of an Isolated Compound (SP-1) from the Seeds of Nirmali (Strychnor potatorum Linn). Journal of Pharmacognosy and Phytochemistry, 2; 1.78.

33. Mastewal, A. (2017). Evaluation of anti-ulcer activity of the leaf extract of Osyris quadripartita Decne. (Santalaceae) in rats. J Exp Pharmacol, 9: $1-11$.

34. Swathi, V. (2017). In-vivo screening of Analgesic and Antiulcer Activity on Carum carvi Seeds. Int J Drug Dev \& Res. 9; 3, 18.

35. Barathane, D., Mythireyi, D., Dhivyashanthi, C. M. (2019). Evaluation of antiulcer activity of ethanolic leaf extract of Coccinia grandis in indomethacin induced gastric ulcer model. International Journal of Basic \& Clinical Pharmacology, 8;4,629.

36. Rasmita, J. (2019). Antiulcer Property of Mussaenda philippica. Pharmacogn J, 11;3: 603. 